\title{
SURFACE-MODIFIED MAGNETIC NANOPARTICLES FOR CELL LABELING
}

\author{
Zasonska Beata A. \\ $\mathrm{PhD}$, Professor, Institute of Macromolecular Chemistry, \\ Academy of Sciences of the Czech Republic \\ office@imc.cas.cz \\ Heyrovskeho Sq., 2, 16206 Prague 6, Czech Republic

\section{Patsula Vitaliy} \\ $\mathrm{PhD}$, Professor, Institute of Macromolecular Chemistry, \\ Academy of Sciences of the Czech Republic \\ office@imc.cas.cz \\ Heyrovskeho Sq., 2, 16206 Prague 6, Czech Republic

\section{Stoika Rostyslav} \\ Doctor of Biological Sciences, Professor, \\ Head of the Department of Regulation of Cell Proliferation, \\ Institute of Cell Biology of National Academy of Science of Ukraine \\ institut@cellbiol.lviv.ua \\ Drahomanov St., 14/16, 79005 Lviv, Ukraine
}

\section{Horák Daniel}

$\mathrm{PhD}$, Professor, Institute of Macromolecular Chemistry, Academy of Sciences of the Czech Republic office@imc.cas.cz Heyrovskeho Sq., 2, 16206 Prague 6, Czech Republic

Abstract. High potential of the polymer-coated magnetic nanoparticles can be envisioned for many biological applications. The particles can be easily magnetically separated and redispersed in water solutions upon removing of the external magnetic field.

Key words: magnetic nanoparticles, surface-modified, cell labeling, iron oxide, thermal decomposition.

\section{Introduction}

A great effort has been recently devoted to (2) the design and synthesis of new magnetic nanoparticles driven by the rapid development of the nanomedicine and nanobiotechnology [1]. Among them, iron oxide nanoparticles, in particular, magnetite $\mathrm{Fe}_{3} \mathrm{O}_{4}$ and maghemite $\mathrm{Fe}_{2} \mathrm{O}_{3}$, nhich play 


\section{ТЕХНИКО-ТЕХНОЛОГИЧЕСКИЕ ИННОВАЦИИ}

a prominent role since iron is indispensable component of living organisms and reduces toxicity [15]. Surface-modified iron oxide nanoparticles have been found very attractive for cell separation [14] and labeling [3], cancer therapy [27], drug delivery [26] and as contrast agents for magnetic resonance imaging (MRI).

There are many methods to obtain various types of iron oxide nanoparticles differing in shape, morphology, size and availability of the reactive groups on the surface. The oldest preparation involves the size reduction [20], i.e. grinding of bulk magnetite in the presence of large amounts of surfactant in a ball mill for 500-1,000 h. Other synthetic approaches for development of magnetic nanomaterials include hydrothermal process [33], sol-gel method [32] or spray pyrolysis [31]. However, the most popular techniques for preparation of such particles include coprecipitation of $\mathrm{Fe}$ (III) and $\mathrm{Fe}(\mathrm{II})$ salts in the presence of an aqueous base (e.g., $\mathrm{NH}_{4} \mathrm{OH}$ or $\mathrm{NaOH}$ ) or thermal decomposition of organo-metalic complexes in high-boiling solvents [12]. For the latter, precursors, such as Fe(III) acetyl acetonate [34], $\mathrm{Fe} N$-nitrosophenylhydroxylamine [24] or $\mathrm{Fe}(\mathrm{CO})_{5}$ were suggested [35]

Iron oxide nanoparticles possess a lot of unique properties, such as small size $(\sim 100 \mathrm{~nm})$ allowing them to function at the cellular level, superparamagnetism, high magnetization and large specific surface area. However, neat (uncoated) particles show high nonspecific adsorption of biomolecules, undesirable in vitro and in vivo interactions, relative toxicity and tendency to aggregate [4]. This can be avoided by their surface modification with biocompatible polymers which also determines ability of the nanoparticles to interact with living cells in a well-defined and controlled manner, as well as ensures immunotolerance and biocompatibility. Typical polymer shells are made from organic, like poly(ethylene glycol) (PEG) [9] poly(vinyl alcohol) [10], poly $(N, N$-dimethylacrylamide) (PDMAAm) [5], or inorganic materials, e.g. silica [16]. This additional layer can render the particles with colloidal stability, avoids interactions with the surrounding environment and introduces specific functional groups on the surface.

In this chapter, synthesis, properties and some applications of new poly $(N, N-$ dimethylacrylamide)-coated maghemite $(\gamma$ $\mathrm{Fe}_{2} \mathrm{O}_{3} @$ PDMAAm), silica-coated maghemite $(\gamma$ $\mathrm{Fe}_{2} \mathrm{O}_{3} @ \mathrm{SiO}_{2}$ ) and methyl-poly(ethyleneglycol)- coated magnetite $\left(\mathrm{Fe}_{3} \mathrm{O}_{4} @ \mathrm{mPEG}\right)$ nanoparticles are described. Both PDMAAm and silica are hydrophilic, chemically inert and biocompatibile materials, hence, they are attractive for drug delivery systems and applications in medical diagnostics. Moreover, the polymerscan behave like transfection agents enabling efficient engulfment of the particles by the cells, e.g. stem or neural cells and macrophages. Macrophages, that are formed in response to an infection and accumulate damaged or dead cells, are important in the immune system [19]. These large, specialized cells can recognize, engulf and destroy foreign objects. Through their ability to clear pathogens and instruct other immune cells, they play a pivotal role in protecting the host. They also contribute to the pathogenesis of inflammatory and degenerative diseases [11]. Labeling of macrophages with magnetic particles enables thus their tracing in the organism using magnetic resonance imaging (MRI).

\section{Preparation of magnetic nanoparticles}

Chemical and physical properties of magnetic nanoparticles, such as size and size distribution, morphology and surface chemistry, strongly depend on selection of the synthetic method, starting components and their concentration [11, 22]. Nanoparticles ranging in size from 1 to $100 \mathrm{~nm}$ exhibit superparamagnetic behavior. In this report, two methods of iron oxide synthesis are presented.

Coprecipitation method. Typical synthesis of magnetic nanoparticles is exemplified by formation of maghemite $\left(\gamma-\mathrm{Fe}_{2} \mathrm{O}_{3}\right)$ during coprecipitation of $\mathrm{Fe}(\mathrm{II})$ and $\mathrm{Fe}$ (III) salts followed by oxidation of $\mathrm{Fe}_{3} \mathrm{O}_{4}$ with sodium hypochlorite [23]. Briefly, 0.2 Maqueousiron(III) chloride $(100 \mathrm{ml})$ and $0.5 \mathrm{M}$ iron(II) chloride $(50 \mathrm{ml})$ were sonicated for a few minutes and mixed with 0.5 Maqueous ammonium hydroxide $(100 \mathrm{ml})$. The mixture was then continuously stirred (200 rpm) at room temperature for 1 hour. Formed $\mathrm{Fe}_{3} \mathrm{O}_{4}$ nanoparticles were magnetically separated and seven times washed with distilled water. Subsequently, the colloid was sonicated with $5 \mathrm{wt} . \%$ sodium hypochlorite solution $(16 \mathrm{ml})$ and again five times washed with water to obtain the final $\gamma-\mathrm{Fe}_{2} \mathrm{O}_{3}$ nanoparticles.

Thermal decomposition. Another possibility to produce superparamagnetic nanoparticles consists in thermal decomposition of iron organic compounds, e.g. iron(III) 
oleate [24]. The method allows preparation of monodisperse $\mathrm{Fe}_{3} \mathrm{O}_{4}$ nanoparticles with controlled size. As an example, we describe preparation of iron(III) oleate by reaction of $\mathrm{FeCl}_{3} \cdot 6 \mathrm{H}_{2} \mathrm{O}$ $(10.8 \mathrm{~g})$ and sodium oleate $(36.5 \mathrm{~g})$ in a water/ ethanol/hexane mixture $(60 / 80 / 140 \mathrm{ml})$ at $70{ }^{\circ} \mathrm{C}$ for $4 \mathrm{~h}$ under vigorous stirring. The upper organic layer was then separated, three times washed with water (30 $\mathrm{ml}$ each) and the volume reduced on a rotary evaporator. Obtained brown waxy product was vacuum-dried under phosphorus pentoxide for $6 \mathrm{~h}$. The resulting Fe(III) oleate (7.2 g) and oleic acid (4.5 g) were then dissolved in octadec1-ene $(50 \mathrm{ml})$ and heated at $320{ }^{\circ} \mathrm{C}$ for $30 \mathrm{~min}$ under stirring $(200 \mathrm{rpm})$. The reaction mixture was cooled to room temperature, the particles precipitated by addition of ethanol $(100 \mathrm{ml})$ and collected by a magnet. Obtained nanoparticles were then five times washed with ethanol $(50 \mathrm{ml})$ and redispersed in toluene and stored.

\section{Modification of the nanoparticle surface}

Disadvantage of neat iron oxide colloids is that they induce undesirable interactions, e.g. adhesion to the cells. To prevent this, it is recommended to coat the iron oxide surface with a biocompatible polymer shell. Surface of the $\gamma$ $\mathrm{Fe}_{2} \mathrm{O}_{3}$ nanoparticles was therefore firstly modified with an initiator and $N, N$-dimethylacrylamide was then polymerized from the surface. 2,2'-azobis(2methylpropionamidine) dihydrochloride (AMPA) served a suitable polymerization initiator. In contrast, if the particles were hydrophobic, i.e. obtained from the thermal decomposition, they were dispersible only in organic solvents. To make them water-dispersible and suitable for biomedical applications, their surface was modified with mPEG derivatives via a ligand exchange.

\subsection{Coating with poly $(N, N)$ - dimethylacrylamide (PDMAAm). \\ Coating of the $\gamma-\mathrm{Fe}_{2} \mathrm{O}_{3}$ nanoparticles with} PDMAAm via grafting from approach is schematically shown in Figure 1. In the following, example of this synthetic approach is described in details. The polymerization was run in a 30 -ml glass reactor equipped with an anchor-type stirrer. First, the AMPA initiator $(4.8 \mathrm{mg})$ was added to $10 \mathrm{ml}$ of the colloid $\left(47 \mathrm{mg} \gamma-\mathrm{Fe}_{2} \mathrm{O}_{3} / \mathrm{ml}\right.$ ) during $5 \mathrm{~min}$, DMAAm $(0.3 \mathrm{~g})$ was dissolved and the mixture purged with nitrogen for $10 \mathrm{~min}$. The polymerization was started by heating at $70{ }^{\circ} \mathrm{C}$ for $16 \mathrm{~h}$ under stirring (400 rpm). After completion of the polymerization, the resulting $\gamma-\mathrm{Fe}_{2} \mathrm{O}_{3} @$ PDMAAm particles were magnetically separated and washed ten times with distillated water until all reaction byproducts were removed. Advantage of the $\gamma-\mathrm{Fe}_{2} \mathrm{O}_{3} @$ PDMAAm particles consists in possibility to introduce additional functional comonomer into the shell to attach a highly specific bioligand, such as antibody, peptide or drug.

3.2. Coating with tetramethoxyortosilicate (TMOS) and (3-aminopropyl)triethoxysilane (APTES).

Another frequently used coating of iron oxide particles is based on silica. Silica is generally synthesized by hydrolysis and condensation of tetraethylorthosilicate (TEOS) or tetramethylorthosilicate(TMOS) (Figure 2). Neat silica particles are obtained by Stöber method in ethanol under

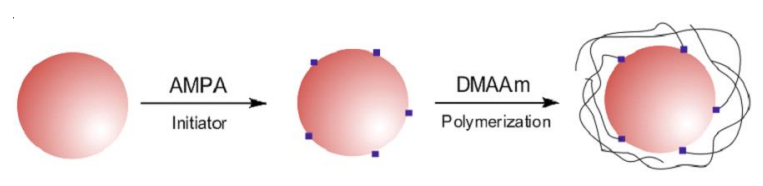

Fig. 1. Scheme of preparation $\gamma-\mathrm{Fe}_{2} \mathrm{O}_{3} @$ PDMAAm nanoparticles via grafting from approach using 2,2'-azobis(2-methylpropionamidine) dihydrochloride (AMPA) initiator

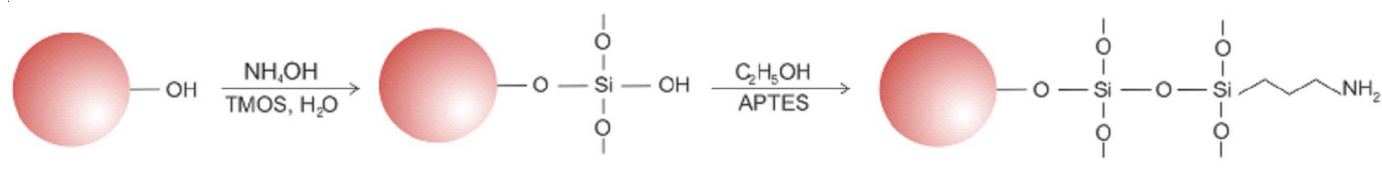

Fig. 2. Scheme of silanization of $\gamma-\mathrm{Fe}_{2} \mathrm{O}_{3}$ with tetramethylorthosilicate (TMOS) and modification of $\gamma-\mathrm{Fe}_{2} \mathrm{O}_{3} @ \mathrm{SiO}_{2}$ nanoparticles with (3-aminopropyl)triethoxysilane (APTES) 
the presence of ammonia catalyst [25] or in surfactant-stabilized reverse microemulsion containing two phases [26]. The $\gamma-\mathrm{Fe}_{2} \mathrm{O}_{3}$ nanoparticles were coated by a silica shell using TMOS according to earlier published method [27]. Shortly, solution containing 2-propanol (24 ml), water $(6 \mathrm{ml})$ and $25 \mathrm{wt} . \%$ aqueous ammonia $(1.5 \mathrm{ml})$ was mixed with $\gamma-\mathrm{Fe}_{2} \mathrm{O}_{3}$ colloid ( $1 \mathrm{ml} ; 50 \mathrm{mg} \gamma-\mathrm{Fe}_{2} \mathrm{O}_{3}$ ) for $5 \mathrm{~min}$. TMOS $(0.2 \mathrm{ml})$ was added and the mixture stirred $(400 \mathrm{rpm})$ at $50{ }^{\circ} \mathrm{C}$ for $16 \mathrm{~h}$. Resulting $\gamma$ $\mathrm{Fe}_{2} \mathrm{O}_{3} @ \mathrm{SiO}_{2}$ colloid (Figure 3, $c, g$ ) was then five times washed with ethanol using magnetic separation. In the next step, amino groups were introduced on the particle surface using (3aminopropyl)triethoxysilane(APTES). In a typical experiment, $\gamma-\mathrm{Fe}_{2} \mathrm{O}_{3} @ \mathrm{SiO}_{2}$ nanoparticles were dispersed in ethanol $(50 \mathrm{ml})$ under sonication for $15 \mathrm{~min}$ and APTES $(0.15 \mathrm{ml})$, ethanol $(20 \mathrm{ml})$ and water $(1 \mathrm{ml})$ were added. After completion of the reaction, the resulting $\gamma-\mathrm{Fe}_{2} \mathrm{O}_{3} @ \mathrm{SiO}_{2}-\mathrm{NH}_{2}$ particles (Figure 3, $d, h$ ) were washed with water.

\subsection{Coating with methyl-poly(ethylene glycol) (mPEG).}

In order to make the hydrophobic iron oxide particles dispersible in water, their surface was modified by a ligand exchange method [28]. As a hydrophilic ligand, mPEG was selected due to its non-toxicity, hydrophilicity and low opsonization in biological media. mPEG was terminated with groups, such as phosphonic $\left(\mathrm{PO}(\mathrm{OH})_{2}\right)[29]$ and hydroxamic $(\mathrm{NHOH})$ acid [30], exhibiting strong interactions with the iron ions. $\mathrm{Fe}_{3} \mathrm{O}_{4}$ particles prepared by thermal decomposition were coated by mPEG terminated with phosphonic (PAmPEG) or hydroxamic acid (HA-mPEG). In the following, the surface modification is described in a more detail. HA- or PA-mPEG $(70 \mathrm{mg})$ and hydrophobic $\mathrm{Fe}_{3} \mathrm{O}_{4}$ nanoparticles $(10 \mathrm{mg})$ were added to $4 \mathrm{ml}$ of tetrachloromethane/toluene mixture $(1: 1 \mathrm{v} / \mathrm{v})$ and sonicated for $5 \mathrm{~min}$. The mixture was then heated at $70{ }^{\circ} \mathrm{C}$ for $48 \mathrm{~h}$ under vigorous stirring. The $\mathrm{Fe}_{3} \mathrm{O}_{4} @$ PEGnanoparticles were purified by repeated precipitation with petroleum ether $(3 \times 30 \mathrm{ml})$ at $0{ }^{\circ} \mathrm{C}$ and diethyl ether $(3 \times 30 \mathrm{ml})$ and redispersed in water.

\section{Properties of the surface-modified iron oxide nanoparticles}

The synthesized surface-modified iron oxide particles were thoroughly characterized by a range of methods including transmission (TEM) and scanning electron microscopy (SEM), atomic absorption spectroscopy (AAS), attenuated total reflectance Fourier transform infrared spectroscopy (ATR FTIR), dynamic light scattering (DLS) and magnetic measurements. Shape of the iron oxide particles prepared by the coprecipitation and thermal decomposition methods was spherical and cubic, respectively. The number-average diameter $\left(D_{n}\right)$ of the $\gamma-\mathrm{Fe}_{2} \mathrm{O}_{3}$ particles prepared by precipitation was $10 \mathrm{~nm}$ (TEM) and polydispersity index PDI $\left(D_{w} / D_{n}\right)=1.24\left(D_{w}\right.$ is the weight-average diameter) suggesting a moderately broad particle size distribution (Figure 3,a). Since it was rather difficult to control size and particle size distribution by the precipitation method, thermal decomposition approach was investigated. Size of the $\mathrm{Fe}_{3} \mathrm{O}_{4}$ particles was controlled in the $8-25 \mathrm{~nm}$ range and monodispersity was achieved (Figure 4). For example, if the reaction temperature increased from 320 to $340{ }^{\circ} \mathrm{C}$, the $D_{n}$ increased from $8 \mathrm{~nm}$ (Figure $4, a$ ) to $17 \mathrm{~nm}$ (Figure $4, b$ ) due to an increase in the growth rate of the nanoparticles. If the concentration of oleic acid stabilizer increased from 0.008 to $0.08 \mathrm{mmol} / \mathrm{ml}$, the particle size decreased from 12 to $8 \mathrm{~nm}$ (Figure 5) because more particles are stabilized. However, the particles prepared by this method were hydrophobic; the organic shell formed $\sim 80 \mathrm{wt} . \%$ of the total mass according to AAS. Such particles formed very stable colloids in organic solvents, such as toluene or hexane, but not in water. Magnetic properties of the nanoparticles were described earlier [22].

Compared with the neat nanoparticles, $D_{n}$ of the dried $\gamma$ - $\mathrm{Fe}_{2} \mathrm{O}_{3} @$ PDMAAm nanoparticles was larger $(12 \mathrm{~nm})$ due to presence of the shell, but the polydispersity substantially did not change (PDI 1.18; Figure 3,b). The hydrodynamic diameter $D_{h}$ of $\gamma-\mathrm{Fe}_{2} \mathrm{O}_{3} @$ PDMAAm, PA - and HA-mPEG-coated $\mathrm{Fe}_{3} \mathrm{O}_{4}$ was substantially larger, i.e. 206,35 and $68 \mathrm{~nm}$, respectively, than $D_{n}$.

The reason consists in that the DLS provided information about $D_{h}$ of the particle dimers and clusters in water, where hydrophilic PDMAAm chains swell. Zeta potential (ZP) of the $\gamma-\mathrm{Fe}_{2} \mathrm{O}_{3} @$ PDMAAm, PA- and HA-mPEG$\mathrm{Fe}_{3} \mathrm{O}_{4}$ was $-53,26.3$ and $12.4 \mathrm{mV}$, respectively. Since ZP of the $\gamma-\mathrm{Fe}_{2} \mathrm{O}_{3} @$ PDMAAm was highly negative, the nanoparticle dispersions were very stable (up to a few months) due to the electrostatic repulsion. 

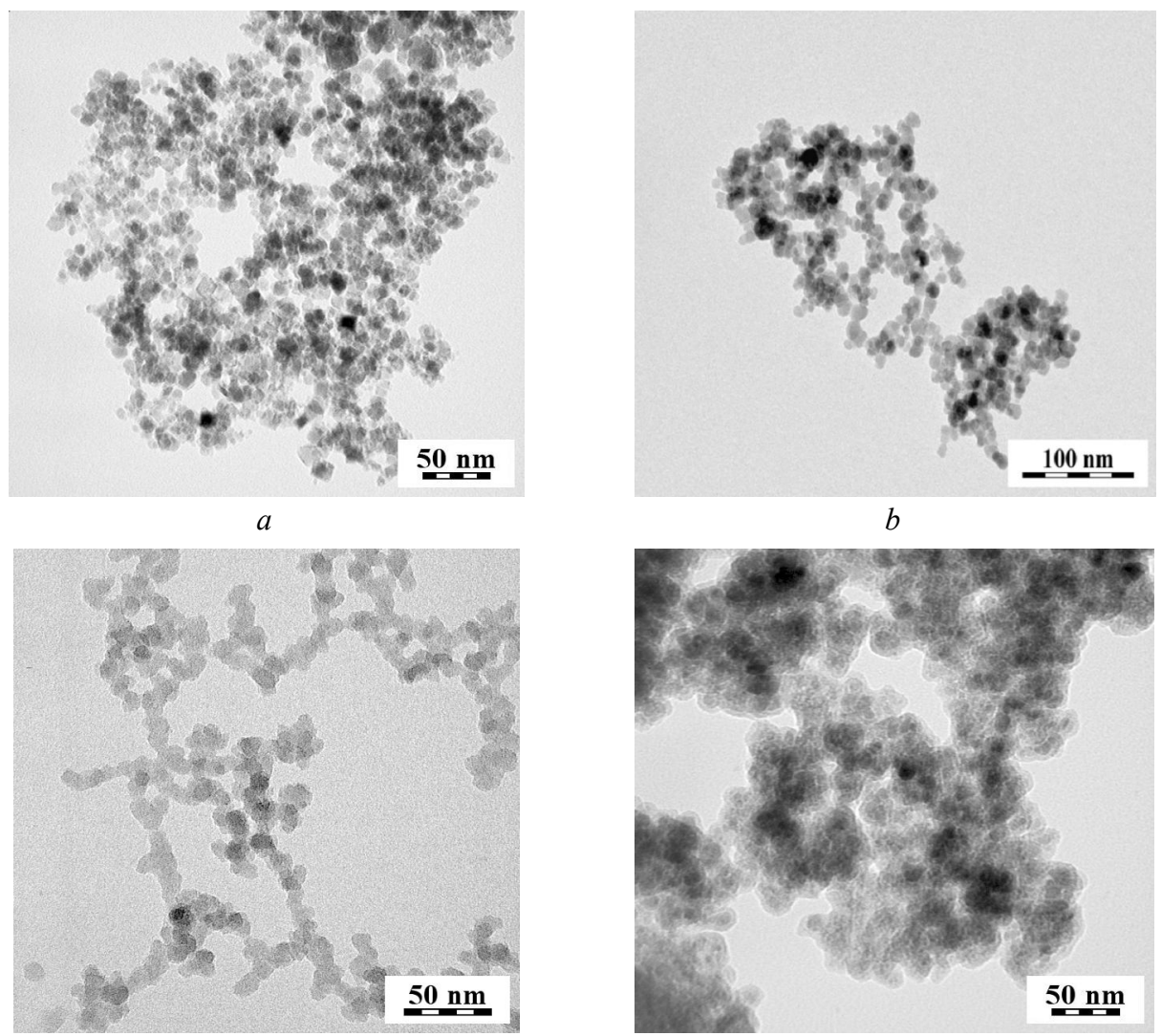

$c$

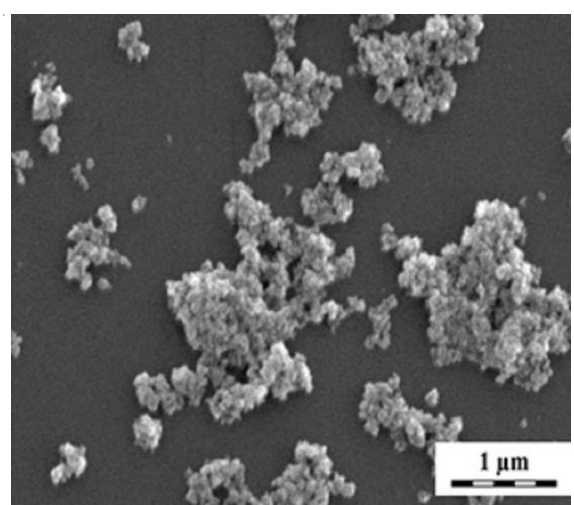

$d$
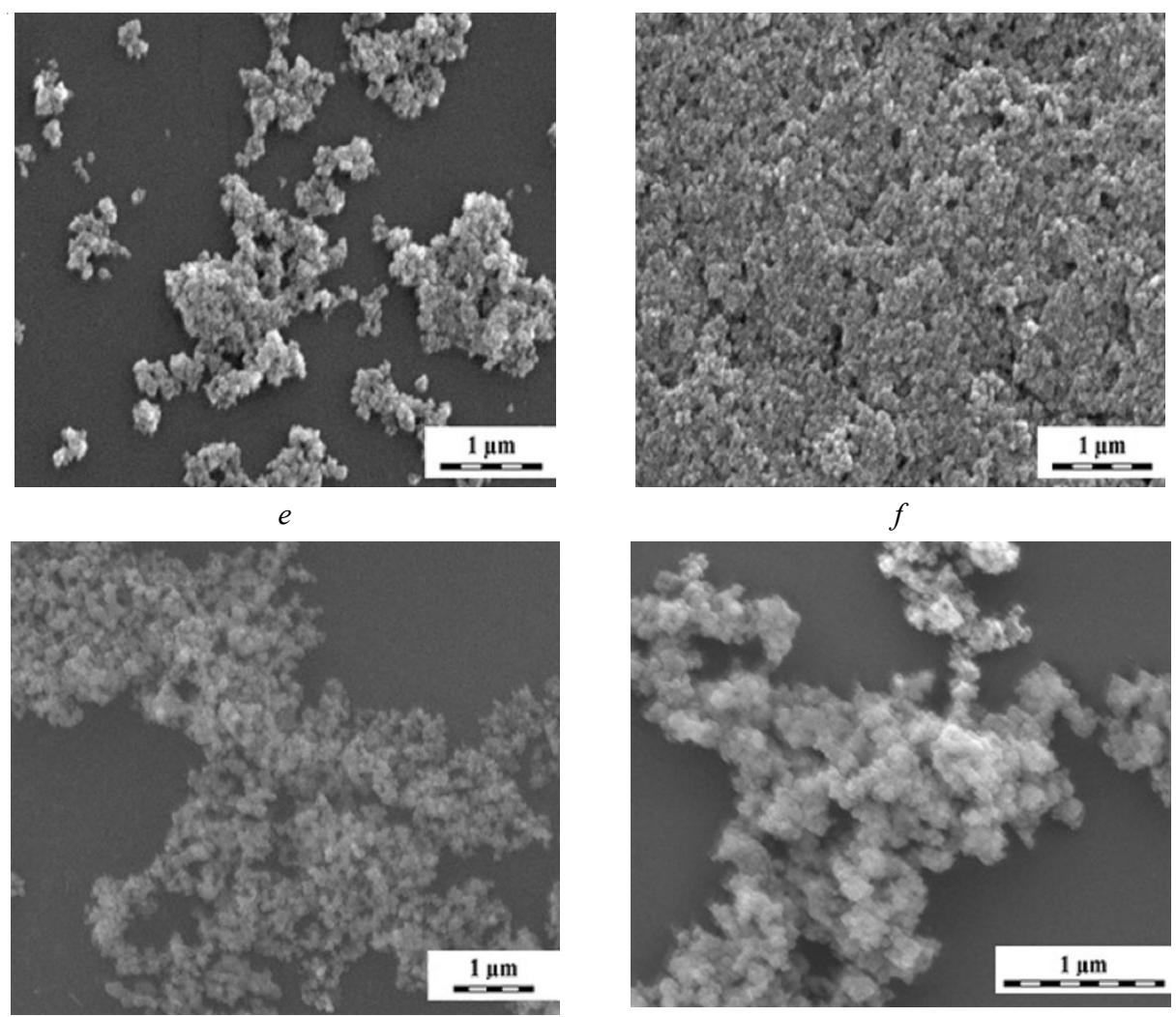

$g$

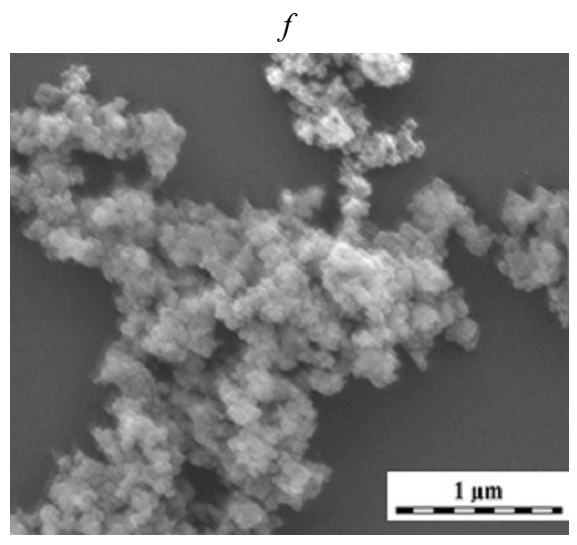

$h$

Fig. 3. ( $(a-d)$ TEM and (e-h) SEM micrographs of $(a, e)$ neat superparamagnetic $\gamma-\mathrm{Fe}_{2} \mathrm{O}_{3}$ nanoparticles synthesized by coprecipitation method, $(b, f) \gamma-\mathrm{Fe}_{2} \mathrm{O}_{3} @$ PDMAAm (via grafting from approach), $(c, g) \gamma-\mathrm{Fe}_{2} \mathrm{O}_{3} @ \mathrm{SiO}_{2}$ and $(d, h) \gamma-\mathrm{Fe}_{2} \mathrm{O}_{3} @ \mathrm{SiO}_{2}-\mathrm{NH}_{2}$ nanoparticles 
Regardless of the low positive ZP of the $\mathrm{Fe}_{3} \mathrm{O}_{4} @$ mPEG particles, their colloid solutions were also very stable due to steric repulsion provided by $\mathrm{mPEG}$. PA-mPEG-Fe $\mathrm{O}_{4}$ colloid $\left(D_{h} \sim 40 \mathrm{~nm}\right)$ was stable also at various $\mathrm{NaCl}$ concentrations ranging from 1 to $1000 \mathrm{mmol} / \mathrm{l}$. In contrast, HA-mPEG-coated $\mathrm{Fe}_{3} \mathrm{O}_{4}\left(D_{h} \sim 65 \mathrm{~nm}\right)$ demonstrated stability only at 1 and $10 \mathrm{mmol}$ of $\mathrm{NaCl} / 1$.ATR FTIR and Fe analysis confirmed successful coating of the iron oxide nanoparticles with both PDMAAm by the grafting method and mPEG by ligand exchange method $[22 ; 36]$.

Optionally, the $\gamma-\mathrm{Fe}_{2} \mathrm{O}_{3}$ nanoparticles were covered with a silica shell at various $\gamma-\mathrm{Fe}_{2} \mathrm{O}_{3} / \mathrm{TMOS}$ ratios $(0.1-0.8 \mathrm{w} / \mathrm{w})$ to control the morphology and size of the nanoparticles observed by TEM (Figure 3,c) and SEM (Figure 3, g). Size of the $\gamma-\mathrm{Fe}_{2} \mathrm{O}_{3} @ \mathrm{SiO}_{2}$ particles ranged from 12 to $192 \mathrm{~nm}$ depending on the $\gamma-\mathrm{Fe}_{2} \mathrm{O}_{3} / \mathrm{SiO}_{2}$ ratio (Figure 6). With increasing amounts of silica relative to the iron oxide and with introduction of amino groups by reaction with APTES, $D_{n}$ of the $\gamma-\mathrm{Fe}_{2} \mathrm{O}_{3} @ \mathrm{SiO}_{2}$ and $\gamma-\mathrm{Fe}_{2} \mathrm{O}_{3} @ \mathrm{SiO}_{2}-\mathrm{NH}_{2}$ nanoparticles increased (Figure 3,d) due to their aggregation. This was accompanied with broadening of the particle size distribution. According to AAS, content of iron decreased from 66.1 in $\gamma-\mathrm{Fe}_{2} \mathrm{O}_{3}$ to 27.7 and 19.8 wt. $\%$ in $\gamma-\mathrm{Fe}_{2} \mathrm{O}_{3} @ \mathrm{SiO}_{2}$ and $\gamma-\mathrm{Fe}_{2} \mathrm{O}_{3} @ \mathrm{SiO}_{2}-$ $\mathrm{NH}_{2}$ nanoparticles, respectively. This was inagreement with increasing thickness of the silica shell surrounding the $\gamma-\mathrm{Fe}_{2} \mathrm{O}_{3}$ particles. Nevertheless, this amount of iron was sufficient to confer the particles with good magnetic properties. Coating of the $\gamma-\mathrm{Fe}_{2} \mathrm{O}_{3}$ particles with a thin silica shell hindered particles from aggregation and made them hydrophilic; as a result, the particles were well dispersible in water. Secondary coating obtained by reaction of $\gamma-\mathrm{Fe}_{2} \mathrm{O}_{3} @ \mathrm{SiO}_{2}$ particles with APTES made possible prospective attachment of a target biomolecule, e.g. protein, antibody, enzyme or drug. However, $\gamma-\mathrm{Fe}_{2} \mathrm{O}_{3} @ \mathrm{SiO}_{2}-\mathrm{NH}_{2}$ nanoparticles often formed aggregates at neutral $\mathrm{pH}$ suggesting that the initial $\gamma-\mathrm{Fe}_{2} \mathrm{O}_{3} @ \mathrm{SiO}_{2}$ particles agglomerated during the reaction with APTES.

\section{Engulfment of the nanoparticles by stem cells and macrophages}

Labeling of the cells with surfacefunctionalized iron oxide nanoparticles is increasingly important for diagnostics and separation of DNA [25], viruses [32], proteins [33] and other biomolecules [34]. A great deal of attention is recently devoted to stem cells and their ability to differentiate in any specialized cell type. Earlier, we have developed poly(L-lysine)-coated $\gamma-\mathrm{Fe}_{2} \mathrm{O}_{3}$ nanoparticles $\left(\gamma-\mathrm{Fe}_{2} \mathrm{O}_{3} @\right.$ PLL) and $\gamma$ $\mathrm{Fe}_{2} \mathrm{O}_{3} @$ PDMAAm particles obtained by the solution radical polymerization in the presence of $\gamma$ $\mathrm{Fe}_{2} \mathrm{O}_{3}$ [5]. Such particles were found to be highly efficient for in vitro labeling of human (hMSCs) and rat bone marrow mesenchymal stem cells (rMSCs). In this report, both $\gamma-\mathrm{Fe}_{2} \mathrm{O}_{3} @$ PDMAAm obtained by grafting approach and $\gamma-\mathrm{Fe}_{2} \mathrm{O}_{3} @ \mathrm{SiO}_{2}$ nanoparticles were investigated in terms of their engulfment by macrophages (Figure 7). This is an important task from the point of view of controlling introduction, movement and overall fate of the labeled cells after their implantation in the organism.

In a typical stem cell labeling experiment, the hMSCs or rMSCs were cultured in Dulbecco's Modified Eagle's Medium (DMEM) in a humidified $5 \% \mathrm{CO}_{2}$ incubator; the medium was replaced every 3 days until the cells grew to convergence. Uncoated, $\gamma-\mathrm{Fe}_{2} \mathrm{O}_{3} @ \mathrm{PLL}, \gamma-$ $\mathrm{Fe}_{2} \mathrm{O}_{3} @$ PDMAAm particles (via the solution polymerization) and the commercial contrast agent Endorem ${ }^{\circledR}$ (dextran-coated iron oxide) were then used for labeling the stem cells. After $72 \mathrm{~h}$ of labeling, the contrast agent was stained to produce Fe(III) ferrocyanide (Prussian Blue). The quantification of labeled and unlabeled cells was performed using TEM and inverted light microscope. Compared with Endorem ${ }^{\circledR}$ and unmodified nanoparticles, the PDMAAm- and PLL-modified particles demonstrated high efficiency of intracellular uptake into the human cells. Optionally, the labeled rMSCs cells were intracerebrally injected into the rat brain and magnetic resonance (MR) images were obtained. MR images of the $\gamma-\mathrm{Fe}_{2} \mathrm{O}_{3} @$ PDMAAm (via the solution polymerization) and $\gamma-\mathrm{Fe}_{2} \mathrm{O}_{3} @$ PLLlabeled rMSCs implanted in a rat brain confirmed their better resolution compared with Endorem ${ }^{\circledR}$ labeled cells $[18 ; 35]$.

In our experiments, both $\gamma-\mathrm{Fe}_{2} \mathrm{O}_{3} @$ PDMAAm (via grafting approach), $\gamma-\mathrm{Fe}_{2} \mathrm{O}_{3} @ \mathrm{SiO}_{2}$ and $\gamma-\mathrm{Fe}_{2} \mathrm{O}_{3} @ \mathrm{SiO}_{2}-\mathrm{NH}_{2}$ nanoparticles $(4.4 \mathrm{mg} / \mathrm{ml})$ were opsonized with FBS proteins at $37^{\circ} \mathrm{C}$ for $24 \mathrm{~h}$. They were then incubated with murine J774.2 macrophages and stained with Acridine Orange and 


\section{ТЕХНИКО-ТЕХНОЛОГИЧЕСКИЕ ИННОВАЦИИ}

Hoechst 33342. Uptake of the particles by the cells and their morphological changes were analyzed using fluorescence microscopy. Cytotoxicity of the $\gamma$ $\mathrm{Fe}_{2} \mathrm{O}_{3} @$ PDMAAm and neat $\gamma-\mathrm{Fe}_{2} \mathrm{O}_{3}$ nanoparticles was estimated using a hemocytometric chamber for counting number of the cells treated in the presence of nanoparticles $(0.025,0.5$ and $1 \mathrm{wt} . \%)$ in the culture medium for $24 \mathrm{~h}$.

The efficiency of the engulfment of the $\gamma-\mathrm{Fe}_{2} \mathrm{O}_{3} @$ PDMAAmand neat $\gamma-\mathrm{Fe}_{2} \mathrm{O}_{3}$ nanoparticles by the murine $\mathrm{J} 774.2$ macrophages was determined after $30 \mathrm{~min}, 1,2,3$ and $24 \mathrm{~h}$ cell cultivation in the presence of the particles. Figure 7 shows Acridine Orange and Hoechst 33342-stained macrophages treated with the nanoparticles for $3 \mathrm{~h}$. After 30-min treatment of J774.2 macrophages with $\gamma$ - $\mathrm{Fe}_{2} \mathrm{O}_{3} @$ PDMAAm nanoparticles, their majority remained unengulfed in the culture medium. Visible engulfment of the nanoparticles appeared after 1-h treatment. After 2-h treatment, granulation of the cytoplasm was observed due to accumulation of the

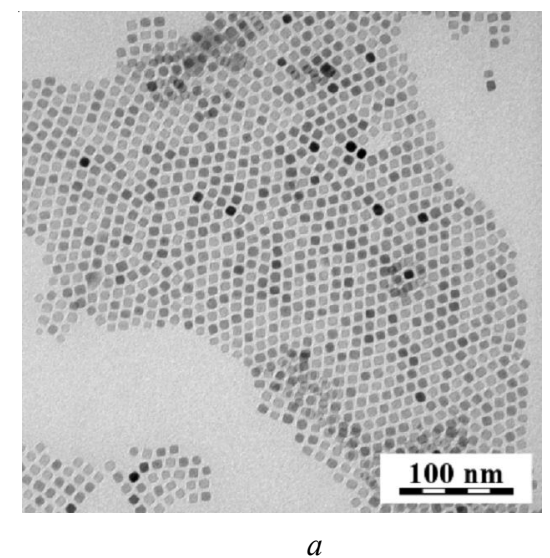

$\gamma-\mathrm{Fe}_{2} \mathrm{O}_{3} @$ PDMAAm nanoparticles in the peripheral region of the cytoplasm. After 3-h treatment, majority of the $\gamma-\mathrm{Fe}_{2} \mathrm{O}_{3} @$ PDMAAm nanoparticles was engulfed by the macrophages and some cells demonstrated signs of lysosomal activation characterized by red Acridin Orange fluorescence. Only a minimal amount of the $\gamma-\mathrm{Fe}_{2} \mathrm{O}_{3} @$ PDMAAm nanoparticles remained unengulfed indicating that the engulfment was very efficient. PDMAAm showed the affinity to cell membrane components facilitating thus the endocytosis.

As a control experiment, the engulfment of the neat $\gamma-\mathrm{Fe}_{2} \mathrm{O}_{3}$ nanoparticles in the macrophages was investigated. Within 1-3 $\mathrm{h}$ treatment, the number of vacuoles, their size, as well as the number of lysosomal clusters associated with large vacuoles, increased with time. Numerous unengulfed $\gamma-\mathrm{Fe}_{2} \mathrm{O}_{3}$ nanoparticles were accumulated on the surface of treated macrophages, while free $\gamma-\mathrm{Fe}_{2} \mathrm{O}_{3}$ nanoparticles were almost absent. The size of the cells treated with $\gamma-\mathrm{Fe}_{2} \mathrm{O}_{3}$ nanoparticles was also increased.

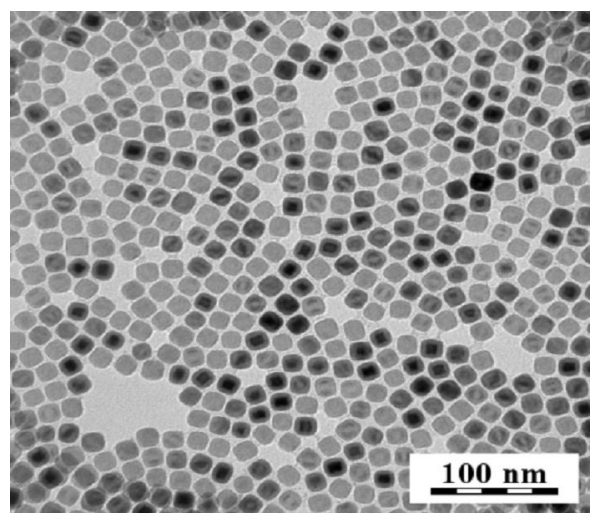

$b$

Fig. 4. TEM micrographs of $(a) 8$ and (b) $17 \mathrm{~nm}$ superparamagnetic $\mathrm{Fe}_{3} \mathrm{O}_{4}$ nanoparticles prepared by thermal decomposition method at (a) 320 and (b) $340^{\circ} \mathrm{C}$

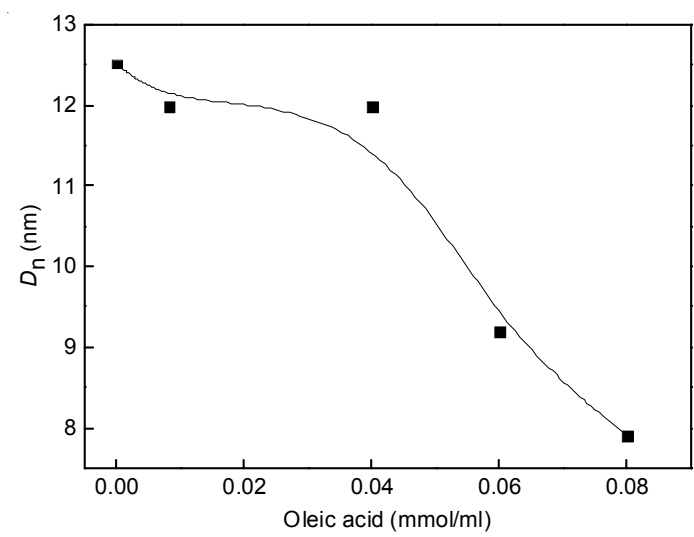

Fig. 5. Dependence of number-average diameter $D_{n}$ of $\mathrm{Fe}_{3} \mathrm{O}_{4}$ nanoparticles on oleic acid concentration. Particles were prepared in octadec- 1 -ene at $320^{\circ} \mathrm{C}$ for $30 \mathrm{~min}$ 


\section{ТЕХНИКО-ТЕХНОЛОГИЧЕСКИЕ ИННОВАЦИИ}

All described superparamagnetic nanoparticles were relatively non-toxic for the cultured cells. Apparently, for the efficient particle engulfment by the macrophages, the presence of positively charged amidine groups in $\gamma-\mathrm{Fe}_{2} \mathrm{O}_{3} @$ PDMAAm nanoparticles is beneficial. The efficiency of engulfment of the $\gamma-\mathrm{Fe}_{2} \mathrm{O}_{3} @$ PDMAAm nanoparticles was quite high since after 2-h treatment most cells engulfed the nanoparticles and only few nanoparticles remained in the culture medium. Fluorescence microscopy confirmed only weak activation of lysosomes, which manifested itself by a change in the color of
Acridine Orange from green to red. Acridine Orange, a weakly basic amino dye, is known to be a lysosomotropic agent. In its stacked form, i.e. in lysosomes, it emits red fluorescence, while in the cell nuclei at neutral $\mathrm{pH}$ it emits yellow-green fluorescence. Activation of macrophages during the engulfment of foreign extracellular materials was accompanied by an increase in the activity of digestive vacuoles and, thus, it caused a red fluorescence shift due to accumulation of the dye in lysosomes. Activation of lysosomal compartments accompanied intracellular processing of the engulfed particles

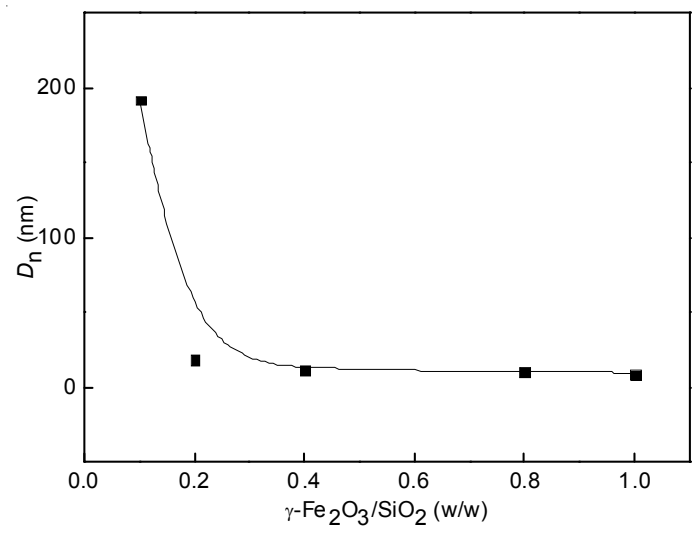

Fig. 6. Dependence of number-average diameter $D_{n}$ of $\gamma-\mathrm{Fe}_{2} \mathrm{O}_{3} @ \mathrm{SiO}_{2}$ particles on $\gamma-\mathrm{Fe}_{2} \mathrm{O}_{3} / \mathrm{SiO}_{2}$ ratio

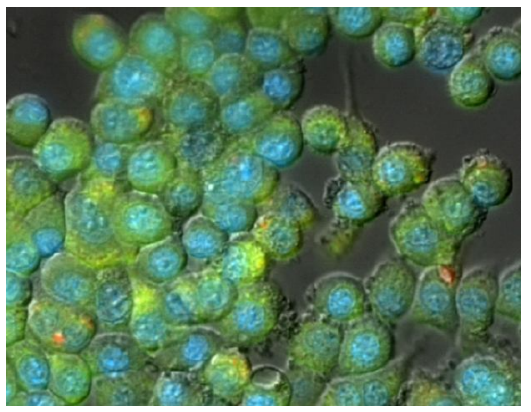

$a$

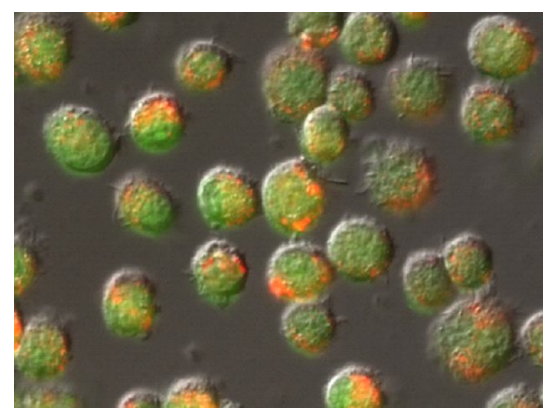

$c$

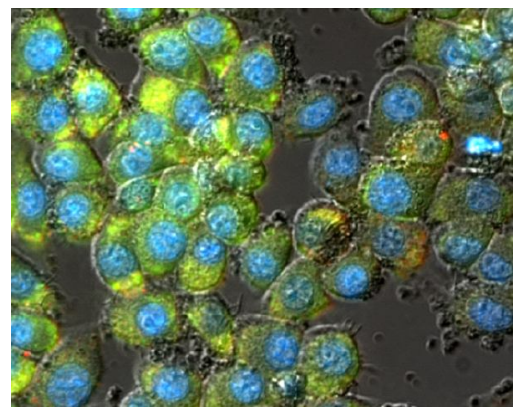

$b$

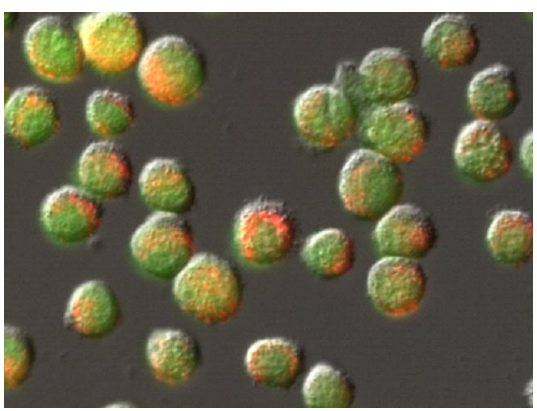

$d$

Fig. 7. Fluorescence micrographs of murine J774.2 macrophages treated with $(a) \gamma-\mathrm{Fe}_{2} \mathrm{O}_{3},(b) \gamma-\mathrm{Fe}_{2} \mathrm{O}_{3} @$ PDMAAm (via grafting approach), (c) $\gamma-\mathrm{Fe}_{2} \mathrm{O}_{3} @ \mathrm{SiO}_{2}$ and $(d) \gamma-\mathrm{Fe}_{2} \mathrm{O}_{3} @ \mathrm{SiO}_{2}-\mathrm{NH}_{2}$ nanoparticles 
(microorganisms, viruses, damaged cells, and foreign macromolecules) [36]. Chemical structure of uncoated $\gamma-\mathrm{Fe}_{2} \mathrm{O}_{3}$ nanoparticles thus provided potential toxicity for the treated cells, which manifested itself by time-dependent evolution of vacuoles in the cell cytosol.

\section{Conclusions}

In summary, two different types of iron oxide nanoparticles were synthesized, maghemite $\left(\gamma-\mathrm{Fe}_{2} \mathrm{O}_{3}\right)$ and magnetite $\left(\mathrm{Fe}_{3} \mathrm{O}_{4}\right)$. The first ones were prepared by coprecipitation of $\mathrm{Fe}$ (II) and $\mathrm{Fe}(\mathrm{III})$ salts with aqueous ammonia. Obtained magnetite was then oxidized with sodium hypochlorite to chemically stable maghemite. However, the size distribution of these particles was rather broad as determined by a range of physicochemical characterization methods including SEM, TEM and DLS measurements. In contrast, monodisperse superparamagnetic $\mathrm{Fe}_{3} \mathrm{O}_{4}$ nanoparticles with size controlled from 8 to $25 \mathrm{~nm}$ were produced by the thermal decomposition of $\mathrm{Fe}(\mathrm{III})$ oleate at different temperatures and oleic acid concentrations. The particles were successfully transferred in water by the ligand exchange method. As a hydrophilic ligand, derivatives of $\mathrm{mPEG}$ with specific functional groups were used that strongly chemically bonded with iron. Optionally, $\gamma-\mathrm{Fe}_{2} \mathrm{O}_{3}$ particles were surface-modified with PLL, PDMAAm (both by the solution radical polymerization and grafting from method) or $\mathrm{SiO}_{2}$. The successful coating of the iron oxide nanoparticle surface was confirmed by both ATR FTIR spectroscopy and Fe analysis. The colloidal particles were stable in aqueous media for several months.

The biotargeting characteristics of the nanoparticles are mainly defined by the biomolecules conjugated to the particle surface.It is desirable that the particle shell contains either membranotropic molecules like phospholipids, poly(ethylene glycol) or macromolecules (proteins) present in biological fluids. In this work, surface of the formed nanoparticles was opsonized with proteins available in the fetal bovine blood serum. The $\gamma-\mathrm{Fe}_{2} \mathrm{O}_{3} @$ PDMAAm and $\gamma-\mathrm{Fe}_{2} \mathrm{O}_{3} @ \mathrm{SiO}_{2}$ nanoparticles, in contrast to the neat nanoparticles were shown to be non-cytotoxic and intensively phagocytozed by the mammalian macrophages. Additionally, there was no cell irritation during the phagocytosis of the $\gamma-\mathrm{Fe}_{2} \mathrm{O}_{3} @$ PDMAAm nanoparticles. In contrast, time-dependent vacuolization of neat $\gamma-\mathrm{Fe}_{2} \mathrm{O}_{3}$ nanoparticles in cytoplasm of the macrophages was observed suggesting cytotoxicity of the material.

Silica used as an inorganic inert coating of the $\gamma-\mathrm{Fe}_{2} \mathrm{O}_{3}$ nanoparticles proved to be also suitable modification agent preventing aggregation of the particles and enhancing their chemical stability. This inorganic material is also easily susceptible to chemical modifications which make synthesis of particles for combined diagnosis and therapy possible. Biological experiments demonstrated that both $\gamma-\mathrm{Fe}_{2} \mathrm{O}_{3} @$ PDMAAm and $\gamma-\mathrm{Fe}_{2} \mathrm{O}_{3} @ \mathrm{SiO}_{2}$ and $\gamma-\mathrm{Fe}_{2} \mathrm{O}_{3} @ \mathrm{SiO}_{2}-\mathrm{NH}_{2}$ core-shell nanoparticles were recognized and engulfed by the macrophages. The uptake of the surface-coated iron oxide nanoparticles by phagocytic monocytes and macrophages could provide a valuable in vivo tool by which magnetic resonance imaging can monitor introduction, trace movement and observe short- and long-term fate of the cells in the organism.

In conclusion, high potential of the polymercoated magnetic nanoparticles can be envisioned for many biological applications. The particles can be easily magnetically separated and redispersed in water solutions upon removing of the external magnetic field. Magnetically labeled cells can be steered and concentrated inside the body by a magnet. The iron oxide particles, modified with organic, as well as inorganic polymer coatings, seem to be very promising not only for cell imaging and tracking, but also for drug and gene delivery systems and capture of various cells and biomolecules required for diagnostics of cancer, infectious diseases and neurodegenerative disorders.

Acknowledgement. The financial support of the Ministry of Education, Youth and Sports (project LH14318) is gratefully acknowledged.

\section{REFERENCES}

1. Akbarzadeh A., Samiei M., Davaran S. Magnetic Nanoparticles: Preparation, Physical Properties, and Applications in Biomedicine. Nanoscale Res. Lett., 2012, vol. 7, pp. 1-13.

2. Alexiou C., Schmid R.J., Jurgons R., Kremer M., Wanner G., Bergemann C., Huenges E., Nawroth T., Arnold W., Parak F.G. Targeting Cancer Cells: Magnetic Nanoparticles as Drug Carriers. Eur. Biophys. J., 2006, vol. 35, pp. 446-450. 
3. Arbab A.S., Bashaw L.A., Miller B.R., Jordan E.K., Lewis B.K., Kalish H., Frank J.A. Characterization of Biophysical and Metabolic Properties of Cells Labeled With Superparamagnetic Iron Oxide Nanoparticles and Transfection Agent for Cellular MR Imaging. Radiology, 2003, vol. 229, pp. 838-846.

4. Baalousha M., Manciulea A., Cumberland S., Kendall K., Lead J.R. Aggregation and Surface Properties of Iron Oxide Nanoparticles: Influence of $\mathrm{Ph}$ and Natural Organic Matter. Environ. Toxicol. Chem., 2008, vol. 27, pp. 1875-1882.

5. Babič M., Horák D., Jendelová P., Glogarová K., Herynek V., Trchová M., Likavčanová K., Hájek M., Syková E. Poly( $N, N$-dimethylacrylamide)Coated Maghemite Nanoparticles for Stem Cell Labeling. Bioconjugate Chem., 2009, vol. 20, pp. 283-294.

6. Bakhracheva Yu.S. Fracture Toughness Prediction by Means of Indentation Test. International Journal for Computational Civil and Structural Engineering, 2013, vol. 9, no. 3, pp. 21-24.

7. Baron A.A, Bakhracheva Yu.S, Osipenko A. Fracture Toughness Estimation by Means of Indentation Test. Mechanika, 2007, vol. 67, no. 5, pp. 33-36.

8. Baron A.A., Gevlich D.S., Bakhracheva Yu.S. Specific Plastic Strain Energy as a Measure of the Cracking Resistance of Structural Materials. Russian metallurgy (Metally), 2002, no. 6, pp. 587-592.

9. Barrera C., Herrera A.P., Rinaldi C. Colloidal Dispersions of Monodisperse Magnetite Nanoparticles Modified With Poly(ethylene glycol). J. Colloid. Interface Sci., 2009, vol. 329, pp. 107-113.

10. Chastellain M., Petri A., Hofmann H. Particle Size Investigations of a Multistep Synthesis of Pva Coated Superparamagnetic Nanoparticles. J. Colloid Interface Sci., 2004, vol. 278, pp. 353-360.

11. Chawla A., Nguyen K.D., Goh Y.P.S. Macrophage-Mediated Inflammation in Metabolic Disease. Nat. Rev. Immunol., 2011, vol. 11, pp. 738-749.

12. Cornell R.M., Schwertmann U. The Iron Oxides: Structure, Properties, Reactions, Occurrences and Uses. $2^{\text {nd }}$ ed. Wiley, Darmstadt, 2000. 273 p.

13. FinnieK.S., Bartlett J.R., Barbé C.J.A., Kong L. Formation of Silica Nanoparticles in Microemulsions. Langmuir, 2007, vol. 23, pp. 3017-3024.

14. Gupta A.K., Gupta M. Synthesis and Surface Engineering of Iron Oxide Nanoparticles for Biomedical Applications. Biomaterials, 2005, vol. 26, pp. 3995-4021.

15. Jeng H.A., Swanson J. Toxicity of Metal Oxide Nanoparticles in Mammalian Cells. J. Environ. Sci. Health A Tox. Hazard Subst. Environ. Eng., 2006, no. 4, pp. 12699-12711.

16. Lu A.-H., Salabas E.L., Schüth F. Magnetic Nanoparticles: Synthesis, Protection, Functionalization, and Application. Angew. Chem. Int. Ed. 46, 2007, pp. 1222-1244.
17. LuY., Yin Y., Mayers B.T., Xia Y. Modifying the Surface Properties of Superparamagnetic Iron Oxide Nanoparticles Through a Sol-Gel Approach. NanoLett., 2002, vol. 2, pp. 183-186.

18. Mohapatra S., Pramanik P. Synthesis and Stability of Functionalized Iron Oxide Nanoparticles Using Organophosphorus Coupling Agents. Colloids Surf., 2009, A 339, pp. 35-42.

19. Mosser D.M. The Many Faces of Macrophage Activation. J. Leukocyte Biol., 2003, no. 73 , pp. 209-212.

20. Papell S.S. Low Viscosity Magnetic Fluid Obtained by the Colloidal Suspension of Magnetic Particles. US Pat., 1965, no. 3, p. 215.

21. Park J., An K.J., Hwang Y.S., Park J.G., Noh H.J., Kim J.Y., Park J.H., Hwang N.M., Hyeon T. Ultra-Large-Scale Syntheses of Monodisperse Nanocrystals. Nat. Mater., 2004, vol. 3, pp. 891-895.

22. Patsula V., Petrovský E., Kovářová J., Konefal R., Horák D. Monodisperse Superparamagnetic Nanoparticles by Thermolysis of Fe(III) Oleate and Mandelate Complexes. Colloid Polym. Sci. DOI: 10.1007/s00396-014-3236-6.

23. Ramis G., Larrubia M. An FT-IR Study of the Adsorption and Oxidation of $\mathrm{N}$-Containing Compounds Over Fe2O3/A12O3 SCR Catalysts. J. Mol. Catal. A Chem., 2004, vol. 215, pp. 161-167.

24. Rockenberger J., Scher E., Alivisatos P. A New Nonhydrolytic Single-Precursor Approach to SurfactantCapped Nanocrystals of Transition Metal Oxides. J. Am. Chem. Soc., 1999, vol. 121, pp. 11595-11596.

25. Saiyed Z., Ramchand C., Telang S. Isolation of Genomic DNA Using Magnetic Nanoparticles as a Solid-Phase Support. J. Phys. Condens. Matter 20, 2008, 204153.

26. Sakka S. Sol-Gel Science and Technology. Springer, San Diego 2005. 535 p.

27. Schleich N., Sibret P., Danhier P., Ucakar B., Laurent S., Muller R.N., Jérôme C., Gallez B., Préat V., Danhier F. Dual Anticancer Drug/Superparamagnetic Iron Oxide-Loaded PLGA-Based Nanoparticles for Cancer Therapy and Magnetic Resonance Imaging. Int. J. Pharm., 2013, vol. 15, pp. 94-101.

28. Semenova L.M., Bakhracheva Yu.S., Semenov S.V. Laws of Formation of Diffusion Layers and Solution of the Diffusion Problem in TemperatureCycle Carbonitriding of Steel. Metal Science and Heat Treatment, 2013, vol. 55, no. 1-2, pp. 34-37.

29. Shapochkin V.I., Semenova L.M., Bakhracheva Yu.S., Gyulikhandanov E.L., Semenov S.V. Effect of Nitrogen Content on the Structure and Properties of Nitrocarburized Steel. Metal Science and Heat Treatment, 2011, vol. 52, no. 9-10, pp. 413-419.

30. Stöber W., Fink A. Controlled Growth of Monodisperse Silica Spheres in the Micron Size Range. J. Colloid Interface Sci., 1968, vol. 26, pp. 62-69. 


\section{ТЕХНИКО-ТЕХНОЛОГИЧЕСКИЕ ИННОВАЦИИ}

31. Strobel R., Pratsinis S. Direct Synthesis of Maghemite, Magnetite and Wustite Nanoparticles by Flame Spray Pyrolysis. Adv. Powder Technology, 2009, vol. 20, pp. 190-194.

32. Sugimoto T., Sakata K. Preparation of Monodisperse Pseudocubic $\alpha-\mathrm{Fe} 2 \mathrm{O} 3$ Particles From Condensed Ferric Hydroxide Gel. J. Colloid. Interface Sci., 1992, vol. 152, pp. 587-590.

33. Viswanathiah M., Tareen K., Krishnamurthy V. Low Temperature Hydrothermal Synthesis of Magnetite. J. Cryst., 1980, vol. 49, pp. 189-192.

34. Willis A., Chen Z., He J., Zhu Y., Turro N., O’Brien S. Metal Acetylacetonates as General
Precursors for the Synthesis of Early Transition of Metal Oxide Nanomaterials. J. Nanomater., 2007, no. 1-7.

35. Woo K., Hong J., Choi S., Lee H., Ahn J., Kim C., Lee S. Easy Synthesis and Magnetic Properties of Iron Oxide Nanoparticles. Chem. Mater, 2004, vol. 16, pp. 2814-2818.

36. Zasonska B. A., Boiko N., Horák D., Klyuchivska O., Macková H., Beneš M., Babič M., Trchová M., Hromádková J., Stoika R. The use of Hydrophilic Poly $(N, N$-dimethylacrylamide) Grafted From Magnetic $\gamma$ - $\mathrm{Fe}_{2} \mathrm{O}_{3}$ Nanoparticles to Promote Engulfment by Mammalian Cells. J. Biomed. Nanotechnol., 2013, vol. 9, pp. 479-491.

\section{ПОВЕРХНОСТНОЕ МОДИФИЦИРОВАНИЕ МАГНИТНЫХ НАНОЧАСТИЦ ДЛЯ СОТОВЫХ МАРКЕРОВ}

\section{Засонска Беата А.}

$\mathrm{PhD}$, профессор института макромолекулярной химии, Академия наук Чешской Республики

office@imc.cas.cz

Площадь Гейровского, 2, 16206 г. Прага 6, Чехия

\section{Патсула Виталий}

$\mathrm{PhD}$, профессор института макромолекулярной химии, Академия наук Чешской Республики

office@imc.cas.cz

Площадь Гейровского, 2, 16206 г. Прага 6, Чехия

\section{Стойка Ростислав}

Доктор биологических наук, профессор,

руководитель Департамента регулирования клеточной пролиферации,

Институт биологии клетки НАН Украины

institut@cellbiol.lviv.ua

ул. Драгоманова, 14/16, 79005 г. Львов, Украина

\section{Горак Даниэль}

$\mathrm{PhD}$, профессор института макромолекулярной химии, Академия наук Чешской Республики

office@imc.cas.cz

Площадь Гейровского, 2, 16206 г. Прага 6, Чехия

Аннотация. Магнитные наночастицы с полимерным покрытием могут быть использованы для многих биологических приложений. Частицы легко отделить с помощью магнитного поля и обнаружить в водных растворах после снятия внешнего магнитного поля.

Ключевые слова: магнитные наночастицы, поверхностно-модифицированный, сотовые маркеры, оксид железа, термическое разложение. 